\title{
The authority of a moral claim: Ian Ramsey and the practice of medicine
}

\author{
G R Dunstan University of Exeter
}

\section{Editor's note}

This paper is the text of the first Ian Ramsey Memorial Lecture which was given by Professor Dunstan in the Examination Schools, Oxford on the 2nd of December 1986 under the auspices of the Ramsey Centre.

Thirty years have passed between my first coming to Oxford to call on Ian Ramsey and my coming today to give the first lecture in his memory for the Centre founded in his name. That first journey proved to be of consequence in my own life, to have opened a new era in Anglican moral reasoning, and to have led Ian into an engagement with moral claims which, perhaps, overwhelmed him in the end. 'We are characteristically ourselves', he once wrote, 'when we acknowledge and respond to the authority of a moral claim, to the vision of moral obligation'(1). This lecture will touch on one arc of that response, in which he met the claim of practitioners in medicine seeking to exercise their profession with integrity in a society convulsed with social change and equipped with new knowledge and power.

It would be superfluous for me to sketch anything of Ian's life and career; that was done in an interim memoir by David Edwards in 1972 (2). It would be presumptuous for me to estimate Ian's contribution to philosophy, theology and the episcopate; that will be done, no doubt, in other lectures. I speak only of that which I know. I need hardly say how honoured I feel at having been invited to do so.

In 1956 the Church of England Moral Welfare Council, of which I was then a servant, had persuaded the Archbishop of Canterbury that the Lambeth Conference of 1958 must give serious attention to contraception in relation both to the nature of marriage and to the problems of population in lands for which the Bishops had pastoral responsibility. Archbishop Fisher told me, in his own words, to 'get on with it'. I knew where to turn for the demographers, the social

\section{Key words}

Ramsey I T; moral claims; abortion; contraception; embryo research; euthanasia; intensive care; sterilisation. scientists, the doctors, the civil servants responsible for social welfare and community development: they were willing to be impressed. I needed a mind, embodied in a person, which could integrate their account of the facts with the subtle reasonings of the interested theologians in a process of moral analysis, moral reasoning and moral prescription - a necessary preparation for the bishops before they met. I did not know Ian then. I think he was suggested to me by Sherwin Bailey or Ena Steel, my colleagues in Church House. I came to meet Ian in Oriel. He responded. The product of our work, a report entitled The Family in Contemporary Society (3), was said by him later to mark 'the beginning of a new era in Christian thinking' (4) It was in this work of twelve to eighteen months that he revealed and developed the skills which he exercised over the next fourteen years.

He was prepared for the exercise. Trained in mathematical as well as philosophical and theological studies, he had caught from Charles Raven a passion for conversation - conversatio, a dwelling together in common business - between science and religion. Since 1954 he had been a member of the Warneford and Park Hospitals Management Committee, and in 1960 he was to become its chairman. In the Lambeth group he mastered the demographic and social surveys prepared by our research assistant, Dr Gertrude Willoughby. Then he set to work with the theologians.

His method, developed then, appeared again in the Oxford group initiated in 1962 by Dennis Whiteley of Jesus College - of which the present Director of the Ian Ramsey Centre was a member - and which produced Biology and Personality (5) in 1965; and in yet another whose papers were collected in Christian Ethics and Contemporary Philosophy (6) in 1966. The method recalls the 'coincidence of opposites' of Nicholas of Cusa. He set men wide apart in mind and starting point, each to expound his case. From each he would then, with delicate courtesy and a sure cut, remove, so to speak, the zona pellucida and analyse the cellular potential of their words. In the Jesus College group he had a vigorous unbeliever in $\mathrm{J}$ Maynard Smith and as vigorous a believer in Alistair Hardy, with God's champion, J W Cole, leaping into the arena whenever God might seem to be in danger. In the Lambeth group he had two theologians as far apart as pole from pole in 
mind, method and personality, D Sherwin Bailey and $G$ B Bentley. In a later sequence of exercises he retained throughout two philosophers very different in mind, Basil Mitchell and R M Hare, so clearly did he see an essential complementarity in philosophical analysis.

He would, I say, draw out each case at its strongest. Then, drawing on his own philosophical mentors Hume and Ryle, it might be, or Strawson and Ayer but drawing chiefly on himself, he would work until he found some point of convergence from which the discussion might proceed or some practical outcome might follow. In the Jesus College group this was in such tenuous but pregnant phrases as 'the need of some conceptual supplement to the theory of evolution', the need of 'some non-scientific supplement' to a 'full neurological account' of human activity, or to 'evolutionary ethics'; the recognition of 'different ways of looking at the same event', from which might come a way to unify the sciences and theology 'without denying the diversity of explanations' (7).

In the Lambeth group he had to be practical. On contraception the bishops had to be given a lead (8). Bentley had argued the hard line that the metaphysical significance and benefit of sexual love attach to a given pattern ex opere operato; to change that pattern would be to make a counterfeit which could not enrich marriage with positive good. Ramsey declared the premiss to be undemonstrable and the adverse judgement on intervention to be undiscriminating. Bailey found his justification for contraception, not in special circumstances like poverty and over-population, but in the nature of marriage itself. Ramsey turned on him a similar question: how do we distinguish between this modification of sexual behaviour and others which are generally condemned in Christian morality - except by insight? On this he built his own analysis.

'This approach to the matter (he wrote) is that of the spiritual adviser rather than that of the ordinary moralist. Those who adopt it do not claim to enunciate incontrovertible Christian principles of universal validity which could stand as axioms for the development of a deductive ethic. The appeal to insight is, in their opinion, fundamental and their concern is to teach those who have decisions to make to bring their particular situations, in all their empirical complexity, alongside other situations in which the Christian response is recognisable through their understanding of the Christian faith.'

At the end comes this typical resolution:

'In spite of the manifest divergences between these three treatments of the question, there is a meetingpoint of practical importance in the judgement that a conscientious decision to use contraceptives would in certain circumstances be justified.'

I may add that it cost me long telephone calls, with
Bentley in Windsor and Bailey in Birmingham, to gain acceptance for this formula, to keep that 'would be justified' from reduction to 'could'. But it served its purpose: the bishops came into line (9).

But what were the bishops doing, when they affirmed a duty of responsible parenthood and a liberty as to the means? They did not enunciate a new moral truth. They did no more than formulate and ratify a moral judgement already widely made in Christian conscience, for which a theological justification was worked out ex post facto. Ramsey, twelve years later, wrote that 'the status of the theology used in the argument was subordinate to the moral claim which, in one way or another, it was endeavouring to articulate' (10).

In Ramsey's own exemplar, incidentally, occur passages which indicate the mind which he would have brought to moral reasoning in today's major question, the status of the human embryo in the therapeutic and research applications of in vitro fertilisation. He had been dissecting the word 'unnatural' as used in the contraception debate. He continued:

"The only sense in which the "unnatural" is wrong is that according to which the "natural" is the perfection of creation towards which we aspire; and the knowledge whereby we are enabled to control the actual and mould it after the image of the ideal comes to us by the grace of God working through the devotion of scientific investigators. If it enables us to deflect the course of gametes into channels through which they will contribute to the making of a better civilisation than would result from their being left alone, it is showing us the way to use actual "nature" for the creation of the ideally "natural".'

In mankind

'there appear creatures capable of development as individuals into citizens of heaven. . . . If it is true that the individual human life begins with the formation of the zygote, then it follows that reverence for the sacredness of life requires of us that we should so control the behaviour of gametes as to make of them the best zygotes that we know how to. If we can enlist in this endeavour the discoveries of medical science, and the ingenuities of modern manufacturing methods, this will not necessarily involve any failure in reverence. On the contrary, the refusal to make use of them might well be held to argue irreverence both towards the Spirit of God in his guidance of doctors and the machine-makers, and towards the true sacredness of life. Any other view seems to imply that superstitious reverence for life which reverences it not as the instrument of God's creative purpose, but as itself, in all its manifestations, God'(11).

Did you notice that if with which the sentence about the zygote began? - 'If it be true that the individual human life begins with the formation of the zygote 
$\therefore$ And Ramsey underlined the word individual. That hypothesis is no longer tenable. Today's embryologists are telling us that the formation of the zygote initiates a pre-embryonic stage of cellular fluidity and totipotency out of which an individual human being may begin to shape at about the fifteenth day - or it may not. And this fact is at the heart of the debate about our liberty and responsibility towards pre-embryonic life. How Ramsey would have enjoyed it!

As soon as the work for the Lambeth Conference of 1958 was done a new enterprise was begun. We advised Archbishop Fisher that Parliament might soon be obliged to revise the law of suicide, which at that time threatened a criminal prosecution for anyone who tried to commit suicide and failed. It would be well to prepare the Church with some analytical thinking. He took the point, and we set to work in a small group: Ramsey, with John Christie, Principal of Jesus, as chairman, Rupert Cross, then a tutor in law at Magdalen, and Doris Odlum, a psychiatrist. We sent drafts of the report (12) to the Home Office as they approached finality.

The result was a surprisingly easy passage for the Suicide Act of 1960 , which abolished the crime of suicide but retained aiding and abetting as an offence. Ramsey's work was characteristic of him. He gave reasons why the traditional Christian view of suicide should be revised, among which was the newly articulated psychiatric understanding of the attempt. He asked what moral insights should be expressed in terms of law and other useful social provision. The most relevant theological ingredient was the Christian attitude to death. There was strong Christian persuasion, therefore, for changing the law, and for promoting better pastoral care in which the clergy would learn from and work with psychiatrists and others professionally competent. His analysis of whether the parish priest should have a discretion to use a proposed alternative service for the burial of a suicide or not was finely nuanced: it concluded that he should have this discretion: 'It is better to risk the highly unlikely occurrence of anomalies than to give the appearance of being, respectively, either rigidly unbending or weakly irresolute, as well as being theologically compromised'.

From this beginning Ramsey applied the method from task to task. At the centre of each group was a core of continuing members: Ramsey, two philosophers complementary in method, a doctor and a lawyer; others were added for special tasks within their own disciplines; and, of course, expert witnesses were invited on specific points.

Sterilisation was tackled next, a task arising from loose drafting by the bishops in their Lambeth Conference of 1958 and from requests for guidance from Christian hospitals in India where vasectomy was being encouraged by the State in the drive to retard population growth. R C Mortimer, Bishop of Exeter, was brought in to chair this group, partly because of his unique standing as an episcopal moralist - he had held the Regius chair in this University - and partly because he had contributed formatively to an earlier report hostile to such medical interference with procreative capacity. Again we had the conjunctio oppositorum. As draftsman I received from Ramsey sheafs of papers annotated, in a minute hand, in all four margins and on the back side. From Mortimer there came a typical note, with wit encoded in the learning:

'My dear Dunstan,

Melior est conditio possidentis, I think, applies. Yours ER E'

The report (13) declared a reluctance to abandon traditional moral judgements against mutilation without good reason. It did, however, extend the concept of necessity into the social dimension, recognising that this would complicate the moral decision while allowing a 'responsible realism' in the rejection of the traditional prohibition. On therapeutic sterilisation it would weigh the gravity of the indication simply in terms of risk and benefit. On sterilisation for eugenic purposes it was cautious; penal and compulsory sterilisation it declared inadmissible. Twenty-four years later, how often is resort to contraceptive sterilisation discussed as a moral issue?

The technology of intensive care has advanced sinco 1964, and the discussion of when to terminate life support systems is a fading candidate for sensation television. Twenty years ago this was not so. Bisho Mortimer opened the discussion seriously, with the quip from Clough, when the British Medical Association (BMA) invited him to address it at a meeting in his diocese, in Torquay. Then a lady from Bristol wrote to the Archbishop of Canterbury to ask whether her husband, whose comatose condition she described, were alive or dead. The Archbishop replied modestly that he didn't know; but the group was already at work on it. Its report, Decisions about Life and Death (14), bears the stamp of Ramsey's mind. At the critical point two cases are argued, one 'utilitarian', by Hare, the other, 'traditional', by Bentley. Ramsey worked these around to a practical conclusion. The report had notable merits: short shrift, for instance, to the undisciplined use of the language of 'love' and of 'doing God's will'; a repudiation of a notional formula 'to give guidance in all cases'; a warning-ignored, alas, N in the USA - of the awful consequences of being able to sue a doctor for not using every available resource for keeping a patient artificially alive against his $\mathfrak{\omega}$ better clinical judgement; an admonition to give serious attention to the emotional stress and troubled 0 consciences of nurses, as well as to the potentially bereft; a clear statement that, while consultation is : essential to the process of clinical judgement, 'society cannot take the duty of decision away from the physician'.

The report was not without consequence. It made its way in the medical literature, and it received 
the compliment of being plagiarised without acknowledgement. For several years, when articles in American journals opened with poor Lear holding his glass to dead Cordelia, their authors betrayed what they had read. Another sequel was more important. We brought Lord Amulree, one of the founding fathers of modern geriatrics, into the group, to our great benefit - and he enjoyed it too. When, at about that time, a clergyman named Edward Shotter came to talk over with me his vision of what was to become the London Medical Group and now the Institute of Medical Ethics, I told him firmly that he must have respected medical backing, for counsel and repute. He took the point, and said, But whom? I sent him to Amulree (15). Their creation began to fulfil what Ramsey knew ought to be done.

Before Decisions about Life and Death was published, the group was launched on work on abortion. If, nearly twenty years after the enactment of the Abortion Act 1967, we pause to reflect on the extent of present practice and the facility of discussion - and facility in this context is meant to recall its cognate facile - we shall recognise how different was the climate in which the group then worked. Termination was a criminal procedure, except in so far as the Bourne judgement had grafted into the law of abortion the defence available to a charge of child destruction (the termination of a viable pregnancy) in the Infant Life Preservation Act, namely that termination was necessary to save the life of the mother. But the Bourne judgement had never been tested on appeal. Doctors, therefore, who operated in good faith were in theory liable to prosecution, while flagrantly illegal abortions occurred in numbers widely guessed at but hard to determine.

Once again, the aim was to anticipate the inevitable legislative reform, to try to secure that the new law, when it came, was a good law. And since Ramsey was appointed Bishop of Durham, with an immediate place in the House of Lords, in 1966, while the debate was at its height, he was involved from beginning to end and his involvement brought him into controversy.

The group's report, Abortion, an Ethical Discussion (16), was perhaps its most thorough work since The Family in Contemporary Society. Read again now, it is still possible to distinguish the paragraphs, the modulations of argument, bearing the imprints respectively of Ramsey and Hare from the straight writing of the draftsman. Note the pattern. First, the facts of the case were established: the state of the law; the stages of embryonic and fetal growth then considered relevant to obstetric care and practice; the indications, medical and other, for terminating pregnancy. Secondly, the moral tradition was taken seriously, focused by a chance remark of Bishop Mortimer - dropped, probably, during lunch - that 'the old moralists gave you forty to eighty days'. Were Ramsey working with us now, I am morally certain about which way his mind would go on the present debate on the status of the pre-embryo in medical research and treatment. He found it 'difficult to envisage a moral discourse appropriate to the cell immediately after conception which was inappropriate before it'; as, indeed, 'it would be hard to maintain an argument either on the inviolability or on the vulnerability of a child viable but as yet unborn, which would not apply also to a child equally developed but prematurely delivered'.

Thirdly, came the reasoned moral analysis. Ramsey and Hare dealt effectively between them with those trump words played as though to take the trick for the absolute protection due to embryonic life: the 'potential' equated with the actual 'human being' or 'person', as though they were equivalent in status. But life was not thereby cheapened. There must be a presumption in favour of life, from conception, growing pari passu with fetal growth, and rebuttable only for grave reason, that is, by the claim of a moral interest stronger than that of the fetus itself. The only such overriding claim admitted was that of the mother to her interest in her own life and - to use the term canonised by the World Health Organisation - her total 'well-being'. None of the other indications then canvassed for abortion - the risk of congenital handicap, and conception as a result of a criminal act was accepted as a ground in its own right. They had circumstantial weight only, as they adversely affected the health and well-being of the mother.

Then came the critical phrase in the report which went into legal history. In determining the gravity of the threat to the mother, 'account may be taken of the patient's total environment, actual or reasonably foreseeable'. A Bill drawn on the basis of the group's criteria had a short run in Parliament. It was then lost, because ALRA (the Abortion Law Reform Association) were better at that sort of Parliamentary management than we were. But in the Bill which became the Abortion Act 1967, when the indications noted, with others, became substantive grounds again in their own right, the environmental clause was left written in. The resultant anomaly, that two doctors could certify a social or economic threat to any existing members of the woman's family as a ground for termination, hindered neither the enactment of the Bill nor the resort to abortion virtually upon demand widespread under it unto this day.

Ramsey, in the Lords, joined with the other bishops in trying to amend the Bill (17). But when it came unamended to the final vote, Ramsey parted from them: he alone voted for the Bill, an action which he felt bound to justify later in a letter to The Times. He voted, he said, for a Bill which he did not want because its rejection would have resulted in a worse situation. His action was consistent with his belief: that moral analysis cannot exclude the foreseeable consequences of any chosen course of action. Among the consequences of a regulative law, however imperfect, rather than a prohibitive law, would be to make a wish for abortion discussable with a doctor or priest or others able to help the mother in her predicament to 
assess possible solutions for it. Ramsey's faith in consultation in which professional skills were pooled was boundless. He was extending into practical action the method which he employed in moral reasoning.

Ramsey had now to share his life with Durham, and therefore with the House of Lords. When, therefore, Lord Raglan introduced his Voluntary Euthanasia Bill, Ramsey's friends, remembering his vote on abortion, smelt danger. I confess to a part in a surreptitious plot. I took him down to St Christopher's Hospice to meet Dr Cicely Saunders. If Ian was ever in doubt about how to meet the moral claim of a human being so miserable as to want to die, Dame Cicely, as she is now, convinced him that there was a better way than to kill him; she gave Ian a vision of the moral obligation of enhancing terminal care. Lord Raglan lost his Bill. But Ramsey did not let the subject go. Prompted, I believe, by the Board for Social Responsibility (which I had left by then), and perhaps by the Institute of Religion and Medicine of which he was a co-founder with Dr Kenneth Soddy (18), he undertook one more working party, on euthanasia. I begged him not to do it: the subject was tired, I argued, and he had far more serious claims upon his time. I failed to move him. The work had hardly begun before he died. The pamphlet, On Dying Well, excellent for its re-direction of the subject from euthanasia to terminal care, was not published until 1975.

As we worked in those groups writing useful little pamphlets, two things became clear. The first was that our group method was sound. The second was that we were practising what I might call symptomatic medicine only: we took up issues one by one as they emerged, instead of planning a long-term strategy of our own. We had superb support from practitioners in the fields in which we worked. We needed now to work more with the theorists, medical scientists in the disciplines basic to the understanding of man, as patient certainly, and also as moral agent. I recall well the staff luncheon at the Ciba Foundation in which Gordon Wolstenholme, then Director, and his senior colleagues listened while I expounded our theme, in a silence made tolerable only by their hospitable table. Somehow it survived their questioning. From this conversation arose a group which met at the Ciba Foundation from May 1967 to October 1970, and which published its work under the title Personality and Science in 1971 (1).

Our question was a simple one: can medical science change personality, and if so, how? and if it can, ought it to? So simple, indeed, that we found no answer. The Ciba Foundation, in the persons of Sir Gordon Wolstenholme and Ruth Porter, called in the scientists, from the British Isles, Switzerland, Denmark, the USA, to contribute their understandings of man and of what their science, when applied, might do to him - in anatomy, physiology, psychology, psychiatry, neurosurgery, endocrinology, pharmacology, criminal pathology, philosophy of education: not, of course, all at the same time, but as the quest developed. Ramsey, with Hare and Mitchell from Oxford, and a lawyer, T E James, and myself from King's College London, drew them out in discussion from prepared papers. It is true to say, I ? think, that as each scientific input was received and worked upon, the philosophical discourse became subordinate - in Ramsey's phrase - to the moral claim. Hare and Mitchell might soar, in a spontaneous philosophical mating flight, on whether man's inner citadel or man's interests offered the better language with which to determine what is to be defended in the defence of man; but the discussion was earthed in practical questions. When does an affliction justify temporal lobotomy or prefrontal leucotomy with its attendant risk of personality change? Under what conditions, if any, may castration be offered to an offender in a penal institution as a condition of release? What chances may be taken with innovative surgery especially in operations on the brain, or with patients whose capacity for consent is impaired by their very condition? What social provisions should be made for the drug addicts whose presence among us is inevitable if the individual's 'right' to experiment is accepted?

Group pressure, in the end, made of Ramsey a contributor as well as animator and referee; he was driven to write on human personality. After characteristic razor-work with words, distinguishing 'temperament', 'character', 'personality' and so on, he found his stride. Personality is to be analysed

'in terms of a distinctive activity, distinctive in bein owned, localised, personalised. The unity of personality is to be found, on this view, in an

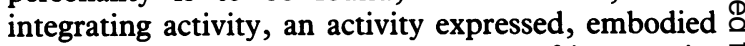
and scientifically understood in terms of its genetic, $\overrightarrow{\overrightarrow{0}}$ biochemical and endocrine, electronic, neurological $\exists$ and psychological manifestations. What we call human behaviour is an expression of that effective, integrating activity, which is peculiarly and distinctively ourselves.'

The goal is not 'normality' but increasingly effective activity within a social group. It is only after this - after justice is done to what he had learned - that he can go on to design a Christian framework in which to assemble $\stackrel{\circ}{\square}$ these presuppositions. Hence he moves to his familiar $\rightarrow$ theme, the ' $I$ ', inerodible as scientific disciplines develop, and 'a presupposition of all scientific $\tilde{N}^{\circ}$ discourse from first to last'. We gain access to ourselves, to our transcendent subjectivity, only by self-disclosure, 'coming alive' - as David 'came alive' $\mathrm{W}$ to Nathan's parable. And the discourse reaches its climax in the words of my text: "We arec characteristically ourselves when we acknowledge and $\mathbb{\complement}^{\circ}$ respond to the authority of a moral claim, to the vision $\stackrel{?}{+}$ of a moral obligation (19).'

Perhaps narrative has dominated this discourse too $\frac{\overrightarrow{0}}{\vec{D}}$ heavily. That is, perhaps, a forgivable product of a $\stackrel{\oplus}{\mathbb{D}}$

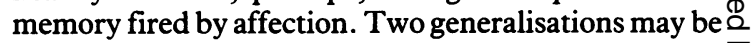
drawn from it. One recalls his method of seeking the 
truth, intellectual and above all, moral. It was this gathering into a common enterprise of people disparate not only in contributory discipline but also in temperament, conviction, fixed habit of mind, that one remembers. There can have been no methodological affinity, for instance, between Ramsey and Mortimer of Exeter, but certainly a deep mutual respect. Yet when Mortimer, in a speech to the Church Assembly, pleaded for a return to the study of natural law, Ramsey was soon drawn into a group essaying the task. And there he brought in H L A Hart with his 'natural necessities' and Hare with his 'moral principles' to help Mortimer 'towards a rehabilitation of natural law' (20). As his fingers moved his mind wove, and a pattern emerged from a diversity of minds, scientific, philosophical and theological alike.

Secondly, does the narrative give any clue to Ramsey's understanding of morality? Certainly he wore no label. Theology, he wrote at the end of Biology and Personality, must be prepared, like science, to admit a certain tentative character in the discourse, including that on Christian morality. 'There can be no final truths or unalterable principles. To think otherwise is to mistake both the character of truth and the character of ourselves as finite' (21). His introductory reflection on the dialogues in Christian Ethics and Contemporary Philosophy ended with the remark, "What becomes quite evident, however, . . . is that Christian morality is no morality of rules, no morality of mere obedience to commands'. Later, in his chapter on natural law, he qualified his enthusiasm for exploring moral claims with "though for many reasons we shall be wise to be cautiously conservative towards the principles we already hold at any given time'. Whatever the diversity of cultures and difficulties of application, on complex issues under rapid social change, 'there will nevertheless be some principles which are so stable as to be virtually sacrosanct as long as human beings remain broadly where they now are'.

'We need moral principles and there are moral principles. But they are not copybook principles, any more than morality is a slavish following of rules. They each point back to an obligation revealed through and around the empirical facts of countless situations, an obligation matched only by a decision in which we realise ourselves characteristically as persons. This is the core of truth, I suggest, in the claims of those who sponsor "situation ethics" and talk of an “existentialist" approach' (22).

Was this an empiricist philosopher's last word in the reconciliation of existentialism with natural law? Perhaps so. But the practical moralist in him spoke again, though in absentia for he was already ill, in his inaugural address to the BMA in Cyprus on 13 April 1972. The moral problems facing medicine, he said, were a special application of 'the general problem of giving a moral direction in applied science in a society where traditional moral absolutes were being questioned, the general problem of ensuring a humane and not a tyrannical technology at a time when society lacked a common morality' (23).

Throughout that spring and summer he was learning, in recuperation, the obverse of the coin in the ethics of medical practice, the reciprocation expected of a patient. In August I had tea with him and Margaret, relaxed and at home, in Auckland Castle. He said he had learned his lesson: he would not go back to the old killing round. But he did. Too soon he was on the London train. On the sixth of October he died. St Paul once said that he was not disobedient to the heavenly vision. Ian might have said that he was not disobedient to the authority of a moral claim.

$G R$ Dunstan is Emeritus Professor of Moral and Social Theology in the University of London and an Honorary Research Fellow in the University of Exeter.

\section{References}

(1) Ramsey I T, Porter R, eds. Personality and science: an interdisciplinary discussion. Edinburgh \& London: Churchill Livingstone, 1971: 130.

(2) Edwards D L. Ian Ramsey Bishop of Durham, a memoir. London: Oxford University Press, 1973.

(3) The family in contemporary society. London: SPCK, 1958.

(4) Ramsey I T. Christian ethics in the 1960 s and 1970s. The Church quarterly 1970; II,3: 221.

(5) Ramsey I T, ed. Biology and personality: frontier problems in science, philosophy and religion. Oxford: Basil Blackwell, 1965.

(6) Ramsey I T ed. Christian ethics and contemporary philosophy. London: SCM Press, 1966.

(7) See reference (5): 5, 7, 191-193.

(8) The family in contemporary society. London: SPCK, 1958. Part reprinted, see reference (6): 340-381.

(9) See reference (8): 130-131.

(10) See reference (4): 222.

(11) See reference (8): $152 \mathrm{f}$

(12) Ought suicide to be a crime? London: Church Information Office, 1959.

(13) Sterilization: an ethical enquiry. London: Church Information Office, 1962.

(14) Decisions about life and death: a problem in modern medicine. London: Church Information Office, 1965.

(15) Dunstan G R. Basil William Sholto Mackenzie 2nd Baron Amulree. Age and ageing, 1984; 13, 4: 193-195. Reprinted in Fournal of medical ethics 1984; 10, 4: 209-210.

(16) Abortion, an ethical discussion. London: Church Information Office, 1965.

(17) Hansard, H of L, 1967 Jul 19, Oct 3 and 23.

(18) Dr Kenneth Soddy died in 1986.

(19) See reference (1): $128 \mathrm{f}$.

(20) See reference (6): Cap. XX.

(21) See reference (6): 195 .

(22) See reference (6): 2, 13, 391, 394.

(23) Ramsey I T. Inaugural address to British Medical Association meeting. Cyprus 1972 Apr 13. British medical journal 1972; Apr 22: $214 \mathrm{f}$. 